\title{
Online support in study skills for international students at UCLAN
}

\author{
Paul Reid, University of Central Lancashire
}

\section{Acknowledgement}

This paper originated as a student project from the Post Graduate Certificate in Enhancing the International Student Experience.

Introduction from Dr Dave Burnapp (Course Leader)

This article reports on an ongoing intervention which makes the case for, and discusses the issues connected with, devising an online pre-arrival study skills package designed for international students embarking on a MSc programme at the University of Central Lancashire. The article makes the case for specific forms of intervention rather than generic approaches: these students are facing not just a movement to a new location, but also to a new level and in some cases are changing from physical sciences to social sciences.

\section{Abstract}

This article highlights the issue of study skills support for international students within the context of an MSc course at the University of Central Lancashire, Preston, UK (UCLAN). It provides an overview of key aspects of international students' study experiences, and analyses UCLAN's, and other Universities' attempts to accommodate the needs of students in this respect. It is a reflective piece of work which reports on the author's involvement in an internationally oriented study skills programme, and aims to present an empathic approach to students' experiences of study in a new country. A course-specific online study skills package is posited as a useful way of enhancing the academic success of international students prior to commencement of study in the UK. The article describes a piece of 'action oriented research' (Small 1995) which will assess the efficacy of such a package with respect to the MSc Applied Public Health at UCLAN.

Keywords: international students; postgraduate skills support; action oriented research 
Dear Chrissie. I'm beginning to think your people were right to look doubtful about this place. It's so cold, oh Chrissie it's so cold. I'm always cold. They gave me a cold clothes allowance when I got to London (I must say they are generous and I do feel grateful-you can tell them that at your end-here there's nobody to tell), but I have to live on it till my first grant comes through ... They've also put the university on the top of a hill, just to make sure it's as windy and cold as possible. And it's quite a way from the town, and the only way you can go to town is on a bus, and the bus stop is underground, and I can't tell you how horrid it is down there-Oh dear. I stopped just now and tried to find something nice to say about this place but I swear I can't ... This is my sixth day here and I haven't talked to anyone except my supervisor for fifteen minutes on Wednesday ... I've started but I don't recognise any of the stuff I'm supposed to read-still, I suppose it will all fall into place ... I think all the people on my floor are on courses together because they all seem to know each other. We say 'Hi' politely in the kitchen and that's about it.

(Souief 1992, pp.335-336)

\section{Literature review}

Souief's depiction of an Egyptian student's experience of study in England gives a vivid account of what it might feel like to embark on a University course in a foreign country. Not only do international students have to contend with feelings of alienation relating to displacement in time and place, they also have to accommodate themselves to an unfamiliar academic environment. They share anxieties with 'home' students who may also feel threatened and anxious at the prospect of starting a University course, but for students who come to a very different cultural and social environment, the levels of anxiety may be even higher (Braham 2006, Johnson 2008).

A fairly extensive literature has focused on the support needs of international students who come to study in the United Kingdom (McLoughlin 1999, Tan 2009, Schmidt et al 2009). This discussion has centred upon the increasing numbers of students from outside the UK choosing to study in this country and the need to ensure that they have a fulfilling and high quality educational experience (Hawkey \& Weir 2008). The literature also focuses upon the response to emotional and psychological needs, as well as the academic support that they may require (Moore et al 2010, Ramos 2010, Bennett Moore et al 2010).

It is important to avoid 'essentialising' international students, however, and treating them erroneously as a homogenous group whose needs are distinct and separate from 'home' students (indeed my use of the word 'them' implies an $u s$ who are doing the defining and who I assume share a similar worldview to myself). This is a divisive and reductionist philosophy which neglects to consider that all students share similar concerns about embarking on University study; be that in terms of anxiety about the unknown, or in terms of clarity around expectations. In Tracy Johnson's work at the University of Bristol, for example, she found that both UK and international students asked for similar types of support; that is, an introduction to what could be expected in academic work, such as critical writing and thinking skills (Johnson 2008). Advice on what is to be expected in UK academic work is something that international students have clearly expressed a desire for, with 
insecurity about tutors' expectations apparently causing a fairly high degree of concern (Lord and Dawson 2002).

Study skills have been identified by both international students and UK academics as an area that needs to be developed (Beekes \& Taylor 2006, Taylor 2006, Ramos 2010). As Souief's quote implies, though, support activities at Universities have needed to focus not only on academic issues, but also on familiarising students with UK culture through social interaction and leisure activities (Dolan \& Macias 2009, UCLAN 2010).

Where the phrase 'study skills' is used it is often presented as if it had an agreed meaning. It can refer, for example, to proficiency in academic skills such as note taking and research (e.g. understanding and using methodologies), and also being proficient in use of a specific language (Hawkey \& Weir 2008). Other commentators distinguish, however, between 'metacognitive' skills or 'learning how to learn' and the more traditional focus on 'skill oriented outcomes', such as referencing, ability to study on one's own or along with others in group work (Allan \& Clarke 2007). Tan, a Chinese student with many years experience of UK higher education, suggests that the key task for international students is to become familiar with the four 'language skills' of reading, writing, speaking and listening with respect to the English language (Tan 2009).

Whilst acknowledging the lack of clarity and possibly ill defined goals of different study support programmes, it is clear that a shared aim has been to familiarise international students with expectations concerning independent, critical enquiry in UK higher education. It should be acknowledged, however, that this notion is itself based on ideas about individuality that culturally diverse learners will not necessarily share (Bennett Moore et al 2010). Study skills support programmes, therefore, must not only familiarise students with what is expected, but also provide opportunities for both academic staff and students to recognise and address differences in world views, in so far as they impact on educational issues. Different cultural beliefs about the purposes of learning have key implications for transmission of study skills objectives, as Dolan \& Macias suggest: 'Referencing can be meaningless if we believe we should integrate learnt knowledge as our own.' (Dolan \& Macias 2009). Referencing and plagiarism have been identified as issues that students from parts of Asia and Africa may find difficulty with when studying in the UK (Kingston \& Forland 2004, Dolan \& Macias 2009). Indeed, student expectations regarding learning experiences vary cross culturally in respect to a variety of parameters. The UK higher education system promotes a view of teachers as facilitators of learning who should be challenged in discussion, for example, whilst some other cultures believe that teachers are authority figures who should rarely, if ever, be challenged by students (Parrish \& Linder-Van Berschot 2010). Students following the latter viewpoint are likely to believe that they should accommodate the teacher's point of view rather than valuing and expressing their own point of view in classroom or coursework.

Academic staff need to reflect upon their cultural presumptions and adapt their teaching methods, whilst simultaneously encouraging international students to reflect upon and transform their own ways of learning. Lecturing staff should make the underlying assumptions of their own academic practice explicit and comprehensible to both home and international students, (Johnston 2008). It has been suggested that this is an aspect of skills induction that is often neglected, however, with most of the pressure being placed on students to scrutinise their attitudes, rather than academics being required to reflect upon and adapt their own approaches (Trahar 2007). The suggestion here is that the underpinning principles of UK higher education have often been left implicit within curricula (and indeed in 
academics' own minds) rather than being made explicit for students to learn about and comprehend.

Study skills programmes have been implemented across Universities in the UK, with some offered as part of an induction programme, and others built into module delivery and courses in a more embedded sense (Allan \& Clarke 2007). Programmes have been targetted at both home and international students together, and also at international students separately (Braham 2006, Taylor 2006, Johnson 2008).

\section{Existing UCLAN Programme}

Within my own School at the University of Central Lancashire views had been expressed by both MSc Applied Public Health students and staff that the School's approach to teaching and learning was not inclusive enough, echoing Koutsantoni's suggestion of a preponderance of 'Anglophone pedagogic models and literacy practices..' (Koutsantoni 2006,p.30). Comments were made by international students about feeling isolated and finding difficulty integrating with home students. Staff had also noticed consistently low grades in coursework submitted by a number of international students.

As a response a study skills package covering the following areas was developed in conjunction with the University's library and learning resources service (LLRS) and made available to both international and home students:

- The philosophy of higher education in the UK

- Searching for data/literature

- Critical reading skills

- Critical writing, critical application of theory/policy to practice

- Planning, structure and presenting coursework

- Referencing/avoiding plagiarism

The course has been delivered primarily by lecturers who taught on the MSc, with input from library and learning resources staff at some sessions. This could be described as an 'embedded' intervention which has linked closely with the MSc course content by utilising coursework submissions to contextualize the relevance of study skills topics. This programme has now run for two years; being offered to, and evaluated positively by both international and home students.

\section{Online Study Skills Support}

Ongoing discussions with international students participating in the MSc Applied Public Health, however, indicate that they still seemed to be finding the transition to UK higher education problematic, in spite of the study skills support offered to date. Module grades and tutorial discussions would seem to support this view. Discussions with new students have highlighted additional concerns about transferring from their previous study of the physical sciences to the discursive social sciences encapsulated within this course.

The course team decided to explore additional avenues of support for international students. The lessons from the variety of literature sources above were taken into account, and it 
became obvious that there was a gap to be filled in preparing students for what they could expect with relation to this particular course before arriving in the UK. Generic online programmes are often offered to international students prior to their arrival in the UK (Bennett Moore et al 2010). Indeed, such an online programme is offered at my own institution (UCLAN 2010). To date though, pre-arrival programmes of this nature tend to be general rather than course specific and targeted at undergraduate, rather than postgraduate students. Where study skills support has been offered in online module taster sessions it has been generalised support, with no specific links to the subject content of the module concerned. In the literature review undertaken for this article there were no examples of case studies, or evaluations of course specific, pre-arrival online study skills programmes. This is the basis of the intervention addressed in this article.

The key point of justification for the proposed intervention is the need for more prolonged and intensive study skills support to international students. The rationale, based on both literature review and personal work experience, is that successful adaptation to a new learning environment is one that needs to be developed over time and initiated at the earliest opportunity in a way which is directly relevant to course content and objectives.

The intervention to be implemented is a pre-arrival online study skills package for international students which will be offered in addition to the existing 'in-course' provision. The online package will offer students the chance to assess their own cultural learning preference, and online tutorials with University staff will allow them to consider how these can be accommodated within the new learning environment which they will join. An online learning style checklist will be adapted for this purpose.

The programme will give a clear indication of the subjects to be studied within the MSc Applied Public Health and will use previous years' coursework materials to illustrate the application and relevance of study skills learning with respect to their particular course. It will be important to offer students the chance to converse with course tutors through 'Breeze' video conferencing technology, as evidence clearly shows the particular value of offering verbal communication as a resource for students whose first language is not English. They may often be nervous and uncertain about their ability to get written ideas across effectively in a second language. A distance learning version of the MSc is currently being considered for international students who do not wish to travel to the UK. This intervention will act as a useful pilot study for the proposed course.

Existing students have also expressed a need for public health work experience. Work placements are currently being negotiated but input from public health practitioners to the construction of the online package will also ensure that it gives a clear indication of public health employment pathways. Library staff will be asked to provide supporting materials to be utilised within the online study skills package.

\section{Evaluation}

The online package will be made available in August 2011 to the coming cohort of prospective students. It will be accessible by all students studying the MSc Applied Public Health, but it is anticipated that it will be used mostly by international, full time students.

A focus group will be convened in November 2011 involving students who have made use of the new online skills package. The loosely structured nature of a focus group discussion 
(Puchta \& Potter 2004, Silverman 2010) will present a useful but informal vehicle for consideration of perceived benefits and disadvantages. Students from the full range of nationalities present on the course will be invited to participate. The number of participants will reflect the general guidance of six to twelve individuals being appropriate for free flowing discussion (Vaughn et al 1996, Morgan 1998).

A second focus group will be convened in February 2012 to allow students to reflect on how the online package prepared them for the coursework and academic experience of the first semester.

Key academic and library staff involved in the creation of the online package will be interviewed to access their perspectives on its effectiveness. Semi-structured interviews will be used to address key questions such as effectiveness when compared with classroom study skills sessions, opportunities for interaction, and perceived relationships with student academic progress. Open questions will allow for detailed comment by participants and offer a richer account than could be obtained by a structured, quantitative approach (Arksey \& Knight 1999).

Focus groups and interviews will be digitally recorded with consent, and transcribed for later analysis. A thematic approach to analysis will be utilised, derived from the constant comparative approach of Grounded Theory (Strauss \& Corbin 2008). Independent analysts will also read transcripts and develop data themes and categories. Subsequent negotiation of data themes between analysts will ensure that the analytical procedure has been as objective as possible and that it has maximised opportunities for authenticity.

A final problem-solving group will be convened in May 2012 involving international student and staff representatives. Participants will consider evaluation findings and design the structure and content of the following year's study skills programme.

Power relationships will be addressed within the evaluation by reassuring participants of anonymity and by creating an atmosphere wherein it is made clear that constructive criticism of lecturers' practice is acceptable and encouraged. The rapport in this sense will hopefully be enhanced by previous encounters in lectures and tutorials.

\section{Research reflections}

As Tan (2009) notes, many international students may feel more comfortable speaking rather than writing English. As this intervention is online it could prove difficult for international students in this respect, albeit that Breeze video conferencing technology would allow some element of verbal and face to face communication. From personal experience I know that such technology does not always function effectively, and depends on the quality of equipment available to respective participants. Such communication forms also lack the immediacy and human warmth that can be conveyed through real, rather than virtual face to face communication. The subsequent interpersonal encounters within the course itself will augment the online encounters, but this could be one possible limitation of this particular type of online intervention.

The online study skills package will hopefully involve contributions from a range of academic staff within my current School. I am aware that staff vary in their willingness to empathize with international students. Some seem very ready to adapt their own academic practices to ensure a better 'fit' with the educational experience of non-UK students; whilst 
others appear to believe that it is solely the international student who needs to make changes to 'fit in' with University expectations. Whilst I am keen to expose international students to as many of their potential lecturers as possible I am hesitant to introduce them to colleagues who I believe may not advance the process of cultural exchange which is so important for the success of this endeavour. This underlines the necessity of involving course teams in prior discussion and training on cultural awareness and respect for differing cultural learning styles. This, or indeed any study skills package, is unlikely to be successful without authentic, considered reflection on the part of practitioners.

The issue of 'change', and who needs to change, is an important one with respect to the likely evaluation of this particular intervention. It is very easy to make judgements on others (colleagues for example) whilst not extending the same levels of scrutiny to our own behaviour. In the case of support for international students I have consistently tried to present a case for UK academics to examine the assumptions underlying their own practice and to adapt that practice to be more inclusive of different ways of learning. In doing this, though, I realize that I have not been as critical of my own behaviour as I should have been.

For all my apparent support for accommodating other world views I realize that I believe the pursuit of independent, critical thought to be the key objective of a University education. I'm aware there are other views of course, but being honest with myself, I believe that becoming an independent, critical thinker is the most valuable attainment of the undergraduate or postgraduate degree process. I realize that this is a culturally bound and conditioned view, and not a universal view to which people from across the world should, or would want to aspire. For me, however, it is what I have come to believe as the goal of a University education. The dilemma for me arises in the realisation that $I$ have been proposing a relativist standpoint regarding the merits of differing educational world-views, whilst 'secretly' espousing an absolutist view of the merits of a Western individualist philosophy.

With respect to the online study skills intervention the question that I, and others involved must ask themselves, is how far are we willing to accommodate students' differing interpretations? That is, interpretations which do not assert the primacy of critical individualism, but indeed assert the primacy of respecting academics' knowledge rather than ultimately challenging it? There is no simple resolution to this dilemma but the way forward I believe lies in trying to understand and respect international students' cultural learning preferences whilst simultaneously demonstrating what is expected in a UK learning tradition. The resolution of the differing experiences must ultimately be the responsibility of the student. Perhaps through the creation of hybrid educational forms we will find new models of learning which are more useful in a globalised world. The opportunities for such hybridisation will increase with the maximisation of chances for cultural academic exchange. The online study skills package will hopefully extend these opportunities.

Although the notion of independent critical analysis will no doubt remain as a guiding principle of UK higher education it is incumbent upon lecturers to find teaching and learning strategies which allow non UK students to demonstrate their skills to the best of their abilities. In assessment, for example, this could mean less focus on essay based assignments, and more opportunities for assessed presentations perhaps, groupwork assignments, or assignments submitted in MP3 format. A possible outcome of the online study skills evaluation could be reorganisation of elements of coursework approaches, to better accommodate the cultural learning preferences of international students. 
The existing research literature clearly attests to the particular value of embedded approaches to study skills, where skills enhancement is offered as an integral part of the course curriculum, rather than as an add-on or initial, induction activity (Cotterell 2001, Allan \& Clarke 2007). Although the online study skills package would introduce students to what is expected regarding the MSc Applied Public Health, it would be supplemented by the classroom based study skills programme which also links skills development directly with the completion of module coursework.

One possible benefit of the online package would be the opportunity to introduce students in a less hectic period (August) to the people they will encounter when attending classroom based sessions and tutorials. This could present a useful chance for developing a rapport that can be difficult to achieve in the hectic work schedules of tutors within the confines of the normal academic year.

Finally, in reflecting on the possible impact of the intervention discussed here, it is pertinent to ask whether the UK education system requires international students perhaps to be 'too independent' (Moore et al 2010)? Study skills programmes aim to acquaint students with independent critical enquiry, but might this independence be difficult to achieve for students who are already grappling with the emotional impact of living in the sort of unfamiliar physical environment depicted in Souief's earlier depiction? In this respect, it will be very useful to encourage previous international students to contribute to the online package, in order to offer guidance and give a clear idea of what MSc Applied Public Health students can expect.

\section{Conclusion}

This article has clearly identified the need for academic support for international students in their transition to study within UK higher education institutions. It has outlined the challenges that international students face, and suggested that a course specific pre-arrival study skills package may assist in easing that transition. The online package will familiarise students with academic and other expectations in advance of their physical arrival in the UK.

The focus group evaluation of the intervention will produce a range of outcomes which cannot be anticipated at this stage, but it is likely that participant feedback will identify a number of changes in our approach to skills development. The subsequent process of evaluation, reflection and development will lead to a more evidence based, and considered approach to meeting the needs of international students studying in the UK.

\section{References}

Allan, J \& Clarke, K (2007) Nurturing Supportive Learning Environments in Higher education through the Teaching of Study Skills: To Embed or Not to Embed? International Journal of Teaching and Learning in Higher Education, 19, (1), 64-76

Arksey, H. \& Knight, P. (1999) Interviewing for Social Scientists, London, Thousand Oaks: Sage

Beekes, W \& Taylor, P. (2006) Integrating Skills Development into the Curriculum Available at: 
http://www.heacademy.ac.uk/assets/York/documents/resources/resourcedatabase/id611_integ rating_skills_development_into_the_curriculum.doc (accessed 18.3.11)

Bennett Moore, Z. Faltin, L. \& Wright M (2010) Critical Thinking and International Postgraduate Students Discourse, 3, (1), 63-94 PRS Subject Centre Available at: http://prs.heacademy.ac.uk/view.html/PrsDiscourseArticles/152 (accessed 18.3.11)

Braham, J. (2006) Supporting the Transition to Studying at a UK HE Institution for First Year International Students at the Leeds University Business School Available: http://www.heacademy.ac.uk/assets/York/documents/resources/resourcedatabase/id615_Supp orting the Transition_to_Studying_at_a_UK_HE_Institution_for_First_Year_International_ Students.doc (accessed 18.3.11)

Cotterell, S. (2001) Teaching study skills and supporting learning. Basingstoke: Palgrave.

Dolan, M. \& Macias, I.(2009) Motivating International Students Economics Network Available at: http://www.economicsnetwork.ac.uk/handbook/international (accessed 11.3.11)

Hawkey, R. \& Weir, C. (2008) Final Project Report: Language, study skill and related issues facing international students in the first year of their MPhil / PhD studies: relevance to institutional language, academic and other support services Centre for Research in English Language Learning and Assessment (CRELLA),University of Bedfordshire Available: http://www.llas.ac.uk/resourcedownloads/2631/hawkey.pdf (accessed 18.3.11)

Huang, R. (2005) Chinese International Students' Perceptions of the Problem Based Learning Experience Journal of Hospitality, Sport, Leisure and Tourism, 4, ( 2) Higher Education Academy

Johnson, T. (2008) Developing Academic Skills with a Diverse Student Body Available at: http://escalate.ac.uk/4913 (accessed 11.3.11)

Kingston, E. \& Forland, F. (2004) Bridging the Gap in Expectations between International Students and Academic Staff. European Conference on Educational Research Post Graduate and New Researcher Pre-Conference, University of Crete Available at: http://www.leeds.ac.uk/educol/documents/00003751.htm (accessed 22.5.11)

Koutsantoni, D. (2006) Definitions: What is Internationalisation in: Leadership Foundation for Higher Education (2006) Leadership Summit 2006: The leadership and development challenges of globalisation and internationalisation London: Leadership Foundation for Higher Education

Lord, P.A. \& Dawson, C. (2002) The Induction Needs of International Students at Postgraduate Level Available at:

http://www.llas.ac.uk/materialsbank/mb080/LO_3/lord_business_sc.pdf (accessed 13.3.11)

Morgan, D. (1998) The Focus Group Guidebook London, Thousand Oaks: Sage

McLoughlin, C. (1999) Culturally inclusive learning on the web, in K. Martin, N. Stanley and N. Davison (Eds), Teaching in the Disciplines/ Learning in Context, Proceedings of the $8^{\text {th }}$ 
Annual Teaching Learning Forum, The University of Western Australia, February 1999, Perth: 272-277

Parrish, P. \& Linder-Van Berschot (2010) Cultural Dimensions of Learning: Addressing the Challenges of Multicultural Instruction, The International Review of Research in Open and Distance Learning. 11, (2) Available at: http://www.irrodl.org/index.php/irrodl/article/view/809/1497 (accessed 22.5.11)

Puchta, C \& Potter, J (2004) Focus Group Practice London, Thousand Oaks: Sage

Ramos, M. (2010) International students in the UK: Friendship networks and their impact on well-being Available at:

http://www.heacademy.ac.uk/assets/York/documents/ourwork/internationalisation/Ramos_Int ernationalstudents_Friendship.pdf (accessed 11.3.11)

Schmidt, L. \& Miller, J. (2009) Peer Assisted Study Sessions to Facilitate Transition for International Students International Journal of Diversity in Organisations, Communities \& Nations, 9, (5), 13-29

Silverman, D (2010) Doing Qualitative Research: a practical handbook London, Thousand Oaks: Sage

Small, S.A. (1995) Action-Oriented Research: Models and Methods Journal of Marriage and the Family 57, Nov.1995, 941-945

Soueif, A. (1992) In the Eye of the Sun London: Bloomsbury.

Strauss, A. \& Corbin, J. (2008) Basics of Qualitative Research: techniques and procedures for developing grounded theory London, Thousand Oaks: Sage

Tan, F. (2009) Tri-Fold Transformation: An International Adult Student's Reflection on Online Learning Adult Learning, Summer/Fall 2009, Vol. 20 Issue 3/4, pp38-40

Taylor, R. (2006) Language Support for International Students and the Internationalisation of the Student Body Available at:

http://www.heacademy.ac.uk/assets/York/documents/resources/resourcedatabase/id616_lang uage_support_for_international_students.doc (accessed 4.3.11)

Trahar, S. (2007) Teaching and learning : the international higher education landscape : some theories and working practices Available at: http://escalate.ac.uk/3559 (accessed 10.3.11)

UCLAN (2010) New International Students' Arrival A to Z 2010

Available at:

http://www.uclan.ac.uk/information/international/student_support/files/14460_Int_New_Arri vals_final_opt.pdf (accessed 18.3.11)

Vaughn, S., Schumm, J.S. \& Sinagub, J. (1996) Focus Group Interviews in Education and Psychology London, Thousand Oaks: Sage 


\section{About the author}

Paul Reid is a Senior Lecturer/Course Leader in the School of Health at the University of Central Lancashire.

Email: PJReid1@uclan.ac.uk 